\title{
"The intervening role of ambidexterity in the knowledge management project success connection"
}

\begin{tabular}{|c|c|}
\hline \multirow{5}{*}{ AUTHORS } & Rawan Alshawabkeh (D https://orcid.org/0000-0003-2451-5474 \\
\hline & Amani Abu Rumman (D https://orcid.org/0000-0002-6557-7463 \\
\hline & Lina Al-Abbadi (D https://orcid.org/0000-0003-2992-2642 \\
\hline & Ayman Abu-Rumman (D https://orcid.org/0000-0002-6388-6051 \\
\hline & R https://publons.com/researcher/AAV-2133-2020 \\
\hline ARTICLE INFO & $\begin{array}{l}\text { Rawan Alshawabkeh, Amani Abu Rumman, Lina Al-Abbadi and Ayman Abu- } \\
\text { Rumman (2020). The intervening role of ambidexterity in the knowledge } \\
\text { management project success connection. Problems and Perspectives in } \\
\text { Management, 18(3), 56-66. doi:10.21511/ppm.18(3).2020.05 }\end{array}$ \\
\hline DOI & http://dx.doi.org/10.21511/ppm.18(3).2020.05 \\
\hline RELEASED ON & Friday, 14 August 2020 \\
\hline RECEIVED ON & Sunday, 08 December 2019 \\
\hline \multirow[t]{2}{*}{ ACCEPTED ON } & Friday, 03 July 2020 \\
\hline & $(\mathrm{cc})$ EY \\
\hline LICENSE & $\begin{array}{l}\text { This work is licensed under a Creative Commons Attribution } 4.0 \text { International } \\
\text { License }\end{array}$ \\
\hline JOURNAL & "Problems and Perspectives in Management" \\
\hline ISSN PRINT & $1727-7051$ \\
\hline ISSN ONLINE & $1810-5467$ \\
\hline PUBLISHER & LLC "Consulting Publishing Company "Business Perspectives" \\
\hline FOUNDER & LLC "Consulting Publishing Company "Business Perspectives" \\
\hline
\end{tabular}

NUMBER OF REFERENCES

60

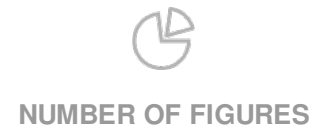

3
NUMBER OF TABLES

3

(C) The author(s) 2022. This publication is an open access article. 


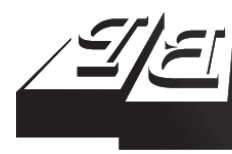

\section{BUSINESS PERSPECTIVES}

(O)

LLC "CPC "Business Perspectives" Hryhorii Skovoroda lane, 10, Sumy, 40022, Ukraine www.businessperspectives.org
Received on: $8^{\text {th }}$ of December, 2019 Accepted on: $3^{\text {rd }}$ of July, 2020 Published on: $14^{\text {th }}$ of August, 2020

() Rawan Al-Shawabkeh, Amani Abu Rumman, Lina Al-Abbadi, Ayman Abu-Rumman, 2020

Rawan AlShawabkeh, Ph.D., Assistan Professor, Business Administration Department, Business School, AlAhliyya Amman University, Jordan.

Amani Abu Rumman, Ph.D., Assistant Professor, Business Administration Department, Business School, AlAhliyya Amman University, Jordan.

Lina Al-Abbadi, Ph.D., Assistant Professor, Business Administration Department, Business School, AlAhliyya Amman University, Jordan.

Ayman Abu-Rumman, Ph.D., Associate Professor, Business Administration Department, Business School, AlAhliyya Amman University, Jordan. (Corresponding author)
Rawan Al-Shawabkeh (Jordan), Amani Abu Rumman (Jordan), Lina Al-Abbadi (Jordan), Ayman Abu-Rumman (Jordan)

\begin{abstract}
Enhanced positive outcomes and benefits require project management to be integrated with knowledge management (KM) to induce ambidexterity and project success. To offer an empirical insight into this issue and advance the field of knowledge further, this research studies the mediating role of ambidexterity within the KM project success connection. The data collected from a sample of 350 senior people who have familiarity with relevant capital projects in the manufacturing companies in Jordan were analyzed using the algorithm of partial least squares (PLS) and bootstrapping techniques. The findings of the study show that KM is an integral aspect of project success, and it has a significant positive effect on project success, but KM, which does not induce ambidexterity, could not significantly enhance project success. KM can induce and stimulate enhanced project performance and benefits only when it induces ambidexterity. This implies that project success requires $\mathrm{KM}$, given that $\mathrm{KM}$ allows organizations to possess exploitative and explorative capabilities simultaneously to tackle issues arising from the external environment. That this study covers only the manufacturing sector in Jordan, the research model can be replicated in other contexts to solidify the findings of the current study.
\end{abstract}

\section{Keywords}

JEL Classification

\section{INTRODUCTION}

Technological advancement has become an enormous transformative global force in the present world, with broad effects on individuals, businesses, and economies by reshaping trade and industry across all sectors and transforming the way businesses operate. Also, there are strong competitions, swift innovation, and short product life cycles. In the bid to weather these challenges, and at the same time, enhance operational efficiency and effectiveness and become cost-effective and schedule-efficient firms, organizations would need to devise new processes. The effective process is knowledge management (KM), given that organizational knowledge management has become indispensable, and the speed at which knowledge transfer is accomplished within the organization could impact the competitive advantage and performance of the organization (Szulanski, 1996). In project management, KM is a strategically important issue (Yang, Chen, \& Wang, 2012).

$\mathrm{KM}$ has been recognized as the most significant change agent and the source of organizational competitive advantage (Nasiruzzaman, Qudaih, \& Dahlan, 2013). KM involves knowledge acquisition, documentation, transfer, creation, and knowledge application (Yahya \& Goh, 2002). It has been held that project success cum KM is crucial to enhancing organizational competitive advantage (Nasiruzzaman, Qudaih, \& Dahlan, 2013). KM is a new development mechanism in the 
new and current era of the knowledge economy. Most corporate organizations are now project-based, and it can be concluded that all operations in the present business environments are being run through the execution of projects. However, Todorović, Petrović, Mihić, Obradović, and Bushuyev (2015) opine that one of the key problems of KM in any project-based organization is the lack and inadequate project results analysis, as well as the absence of accurate documentation on the outcomes from past projects.

In the present, organizations have been focusing on project success and achievement of project objectives by adopting managerial processes that would afford the managers a good opportunity to succeed in achieving their goals (Nasiruzzaman, Qudaih, \& Dahlan, 2013). The managerial process that could be adopted is KM, given that KM factors have been identified to have had a significant influence on project success (Nasiruzzaman, Qudaih, \& Dahlan, 2013). KM plays a big role in any successful project (Nasiruzzaman, Qudaih, \& Dahlan, 2013). Hanisch, Lindner, Mueller, and Wald (2009), Ajmal, Sandhu, and Jabeen (2013), and Yun, Shin, Kim, and Lee (2011) suggested that information about a project can be created by evaluating and reviewing project outcomes, emphasizing the necessity to gather information on project quality and progress with the need to conduct lesson learned reports to create a knowledge-based database to improve the performance of a future project.

The possession of dynamic capabilities is related to ambidexterity. This is because ambidextrous organizations can handle the environmental challenges, meet today's demands effectively, and be capable of being adaptive to handle the changing market conditions (Zhang, Wei, \& Constance, 2019; Lis, Józefowics, Tomanek, \& Gulak-Lipka, 2018; Tushman \& O’Reilly, 1996).

Literature has identified the relationship between ambidexterity and $\mathrm{KM}$, and between ambidexterity and project success, but to attain a deep perception and advance the knowledge field further, this study examines the mediating role of ambidexterity in the nexus of the KM project success, aiming to build up an understanding about accomplishing ambidexterity in the project-based environment. According to Todorović, Petrović, Mihić, Obradović, and Bushuyev (2015), KM in the project environment has not been adequately investigated in project management research field, and not many researches have been done regarding the KM project success nexus, indicating that the understanding concerning the role of $\mathrm{KM}$ on the performance and success of projects need to be increased (Yang, Chen, \& Wang, 2012). The available studies on the impacts of KM fall short of explaining its connection with ambidexterity.

Given the above explication, this study investigates the effect of KM on project success and ambidexterity's mediating role in KM's relationship with project success and performance in Jordan's manufacturing sector. As projects are being used widely in the Jordanian manufacturing companies, it is thus apposite to assert that the manufacturing industry in Jordan is project-based. Therefore, it is crucial to identify factors that contribute to project success in the industry. Besides, it is worthwhile to investigate the Jordanian manufacturing companies because it is the second biggest industrial sector in Jordan after the services sector, and it contributes $18.17 \%$ to the GDP in 2016 (GlobalEDGE, 2018). This study's remainder involves hypotheses development, methodology, result, discussion of findings, and conclusion.

\section{LITERATURE REVIEW AND HYPOTHESES}

Project success refers to the project completed within time, cost, and quality (Prabhakar, 2008). According to Turner (2009), however, a project may be completed on time and cost, but it may be considered a failure a few years later. Therefore, project success has attracted various connotations. In
Kerzner's (2011) arguments, it is difficult to predict whether a project is successful or not. Project success, as posited by Turner (2009), should be characterized with seven requirements: the project should increase the shareholder price that belongs to the parent organization; the project should yield a profit; the project should yield a specified improvement in efficiency; the newest advantage should work as expected; the newest advantage should yield the 
item or provide something people would want to buy; the latest advantage should also be easy to operate; the project should also be performed timely, on a budget basis, and with the value specified; the project workers should have sufficient expertise, and the project should meet their expected needs; the companies should benefit monetarily. Overall, the success of a project is based on fundamental project factors, cost (budget), time (schedule), performance (quality) of the completed result with predefined impacts and benefits.

Moreover, many studies (e.g., Turner, Keegan, \& Crawford, 2004) have indicated that getting knowledge is critical to project success, and project success is contingent on both project learning and project performance (Arthur, DeFillippi, \& Jones, 2001). Prior research (Yang, Chen, \& Wang, 2012) also acknowledged KM to be playing a very important role in the performance of projects. Also, KM has been connected with crucial factors of performance outcomes (Robinson, Carrillo, Anumba, \& Al-Ghassani, 2005; Liu, Chen, \& Tsai, 2005). The organizational efforts to enhance knowledge generation and utilization represent what is called $\mathrm{KM}$ (Fedor, Ghosh, Caldwell, Maurer, \& Singhal, 2003). There have been some research efforts geared towards the demystification of KM from the organizational perspectives, but the success of such efforts would consequently hinge on other research efforts expanding the understanding of KM impacts in the project management research field.

The extant literature (Yang, Chen, \& Wang, 2012; Liu, Chen, \& Tsai, 2005) has identified KM as a significant predictor of project success. According to Yang, Chen, and Wang (2012), KM has been positively associated with project success, and that project outcomes are more likely to be achieved with some higher levels of KM. Briefly, the prior literature has shown that KM plays a major role and delivers benefits that are very significant to organizational projects' success.

Leveraging the results of many studies on KM's benefits is based on the notion that the skilled and knowledgeable workforces are the most valuable resources of an organization. In managing knowledge, firms use little formal managerial procedures (Styhre \& Gluch, 2010). Therefore, new and innovative knowledge tools are indispensable and per- ilous to mitigate many unfavorable effects of power associated with bureaucratic knowledge practices in organizations (Sage, Dainty, \& Brookes, 2010). Besides, knowledge is a crucial organizational resource that can enhance the competitive advantage of an organization.

Knowledge is concerned about knowing 'what', 'how' and 'why', including descriptions, information, facts, evidence, or skills based on education and/or experience. KM also comprises "knowledge identification, knowledge generation, knowledge storing, knowledge dissemination, knowledge applying, and knowledge evaluation" (Al-Hawary \& Alwan, 2016). Knowledge could be explicit (i.e., the formal knowledge, which could be captured, stored, and distributed) or tacit (i.e., personal insights, feelings, and perceptions) (Santo, 2005). Knowledge is created through the interaction between explicit and tacit knowledge.

$\mathrm{KM}$, which refers to knowledge acquisition, documentation, transfer, creation, and knowledge application (Yahya \& Goh, 2002), has been recognized as the main mechanism for change in this new and recent era of the knowledge economy (Al-Zayyat, Al-Khaldi, Tadros, \& Al-Edwan, 2010). KM plays a big role in any successful project, and any successful project would have objectives that would focus on knowledge as an asset. This includes knowledge creation, knowledge access improvement, knowledge environment enhancement, and KM.

The literature review has also identified $\mathrm{KM}$ as a significant determinant of project success. KM is positively associated with project success, and that project outcomes are achievable using higher levels of KM (Yang, Chen, \& Wang, 2012). Nasiruzzaman, Qudaih, and Dahlan (2013) suggest that KM factors can significantly influence project success. According to Cleland (1994), successful projects are the cornerstone to implement the successful changes in an organization, which, in the long run, facilitates the accomplishment of organizational strategic objectives (Nasiruzzaman, Qudaih, \& Dahlan, 2013).

Summing up the inferences from the extant literature (Nasiruzzaman, Qudaih, \& Dahlan, 2013; Yang, Chen, \& Wang, 2012), knowledge-sharing and successful knowledge dissemination have 
been regarding as the key ingredients for project success. Moreover, as indicated earlier in this study, many studies have signified that $\mathrm{KM}$ is a positive driver of project success. However, the rigidities of project management, which could impede the flexibility required for effective project management in the present-day dynamic business and operational environment, organizations are likely to face complications in handling the rapidly changing environments (Candi, Van den Ende, \& Gemser, 2013; Lenfle \& Loch, 2010). Ambidextrous capabilities are a prerequisite for effective organizational handling of dynamic environments (Tamayo-Torres, Roehrich, \& Lewis, 2017; Güttel \& Konlechner, 2007).

Organizational ambidexterity is an organization's willingness to navigate the market and surrounding environment simultaneously (Petro, 2017) and reallocate resources and competencies to address new opportunities and threats (O'Reilly \& Tushman, 2011). In addition to accumulating and utilizing its knowledge (March, 1991), it will enhance superior performance and sustainability (Kim, Lim, \& Yoo, 2019). Ambidexterity helps to gain the simultaneous capacity to effectively exploiting the existing capabilities and exploring new opportunities (Raisch, Birkinshaw, Probst, \& Tushman, 2009), attains alignment in its present processes while familiarizing effectively with environmental difficulties (Gibson \& Birkinshaw, 2004), Managers try to solve the current problems while at the same time having the ability to face the future challenges and shifts (Gibson \& Birkinshaw, 2004). Organizational ambidexterity plays a role in enhancing an organization's competitiveness, high-level performance, organizational success, and survival (Raisch \& Birkinshaw, 2008). Besides, it is indicated in March's (1991) study, which is among the earlier researches on organizational ambidexterity, that organizations should possess simultaneous exploitation and exploration capabilities to address problems emerging from the external environment. KM in project environment has not been adequately investigated in project management research field, and not many studies have been done regarding the KM project success nexus, indicating that the understanding of the role of $\mathrm{KM}$ in the performance and success of projects need to be increased (Yang, Chen, \& Wang, 2012). The available studies on the impacts of KM fall short of explaining its connection with ambidexterity.

Owning to the above discussion and the quest to achieve a deep insight and advance the field of knowledge further, this research studies the mediating role of ambidexterity in $\mathrm{KM}$ project success nexus. Therefore, the hypotheses of this study are as follows:

\section{H1: KM has a positive effect on project success.}

H2: Organizational ambidexterity mediates the relationship between KM and project success.

\section{RESEARCH MODEL}

This study reviewed the appropriate and related literature to develop the hypotheses and the corresponding model and framework for this research. As depicted in Figure 1, which represents this study's research framework, three variables (KM, ambidexterity, and project benefits) had been investigated in the current study. This study enhances the current literature by offering important results on identifying the intervening role of ambidexterity on the relationship between KM and project success.

Source: Authors.

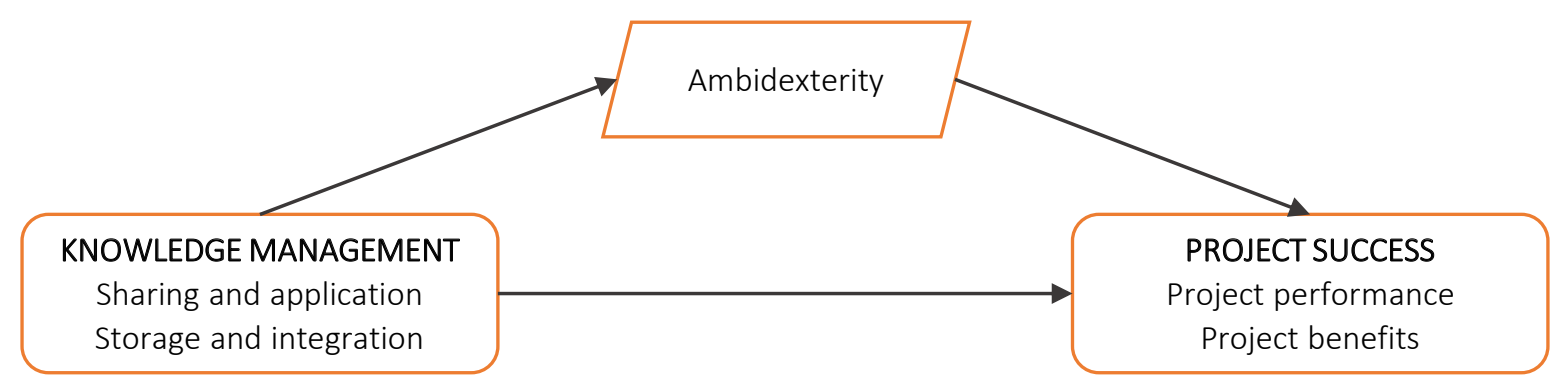

Figure 1. Research model 


\section{RESEARCH METHODS}

This research employs a cross-sectional research design in that the data were collected once for the study and later analyzed and interpreted statistically to generate the conclusion or make inferences concerning the study population. A cross-sectional research design is chosen because it is cost-effective, time- and money-saving (Sekaran \& Bougie, 2010; Wilson, 2010). Through SmartPLS 2.0 M3 software, the data from the study, which were project-specific and thus meant that the data were representative of the KM levels used in projects, were analyzed as this would ensure that measurement errors are minimized and properly ensure the highest precision (Hair, Black, Babin, \& Anderson, 2010). Besides, the analysis technique included a two-step approach in the current study: examination (the measurement model) and structural model as proposed by Anderson and Gerbing (1988), Fornell and Yi (1992), and Hair, Black, Babin, and Anderson (2014), as this will ensure reliable and scientifically valid results.

\subsection{Population and sampling}

Furthermore, the Jordanian manufacturing industry is the population in this study. The selected manufacturing companies cut across many industries, including fabricated metal products, electronics, paper-based industry, textile, and garment. The respondents were senior individuals who were familiar with the development of capital projects and could answer the survey questions. The sample size of the study is 400 , and respondents are chosen using a systematic technique.

Thus, the respondents were given 400 questionnaires, but a total of 350 questionnaires were retrieved, and all of those questionnaires were valid for analysis, representing a response rate of 88 percent. According to Sekaran (2003), this response rate to the questionnaire is considered acceptable and adequate. Demographically, 135, representing $39 \%$ of the respondents of this study, are executive directors in various firms, while 215 (61\%) are architects. Regarding the years of experience, 188 respondents representing 54\% have between 6 and 15 years of experience, while 95 respondents representing $27 \%$ have between 16 and 25 years of experience. 67 respondents representing 19\% have
26 or above years of experience. Additionally, the respondents have been engaged in numerous projects. 123 (35\%) respondents have been engaged in more than ten projects, but most respondents have been involved in more than 15 projects.

\subsection{Measurements}

The questionnaire is the tool through which the data were collected, and this is considered suitable because it is a common tool for data collection (Keeter, 2005). The measurement used for KM was adapted from Huang and Li (2009) and Chen and Huang (2009), while the measures of project success were adapted from Pinto and Slevin (1988), and Gelbard and Carmeli (2009). Project success was measured with both project benefits and project performance. Each item was evaluated on a seven-point scale ranging from 1 (strongly disagree) to 7 (strongly agree). Ambidexterity, which is considered a multidimensional construct involving the multiplicative interaction of exploration and exploitation (Revilla, Prietto \& Rodríguez, 2011), was measured with eight items: four items concern exploration and other four items concern exploitation. The measurement was adapted from Katila and Ahuja (2002) and He and Wong (2004).

\section{RESULTS}

Hypotheses' testing was done using two-step approaches of measurement and structural model. As specified by Variance-Based Structural Equation Model analysis, evaluation of the measurement model must be performed to indorse internal consistency, reliability, discriminating validity, and convergent validity (Hair, Black, Babin, \& Anderson, 2014).

According to the results in Table 1, Table 2, and Figure 2, each element contained in the constructs illustrates a higher value for their respective constructs, which enhances significant and acceptable factor loadings. This affirms the convergent and content validity of each of the constructs. All the items showed satisfactory factor loadings that ranged between 0.632 and 0.897 , and composite reliability scores ranged between 0.866 and 0.905 , those higher values indicated higher levels of internal consistency reliability (Hair, Hult, Ringle, \& 
Source: Authors.

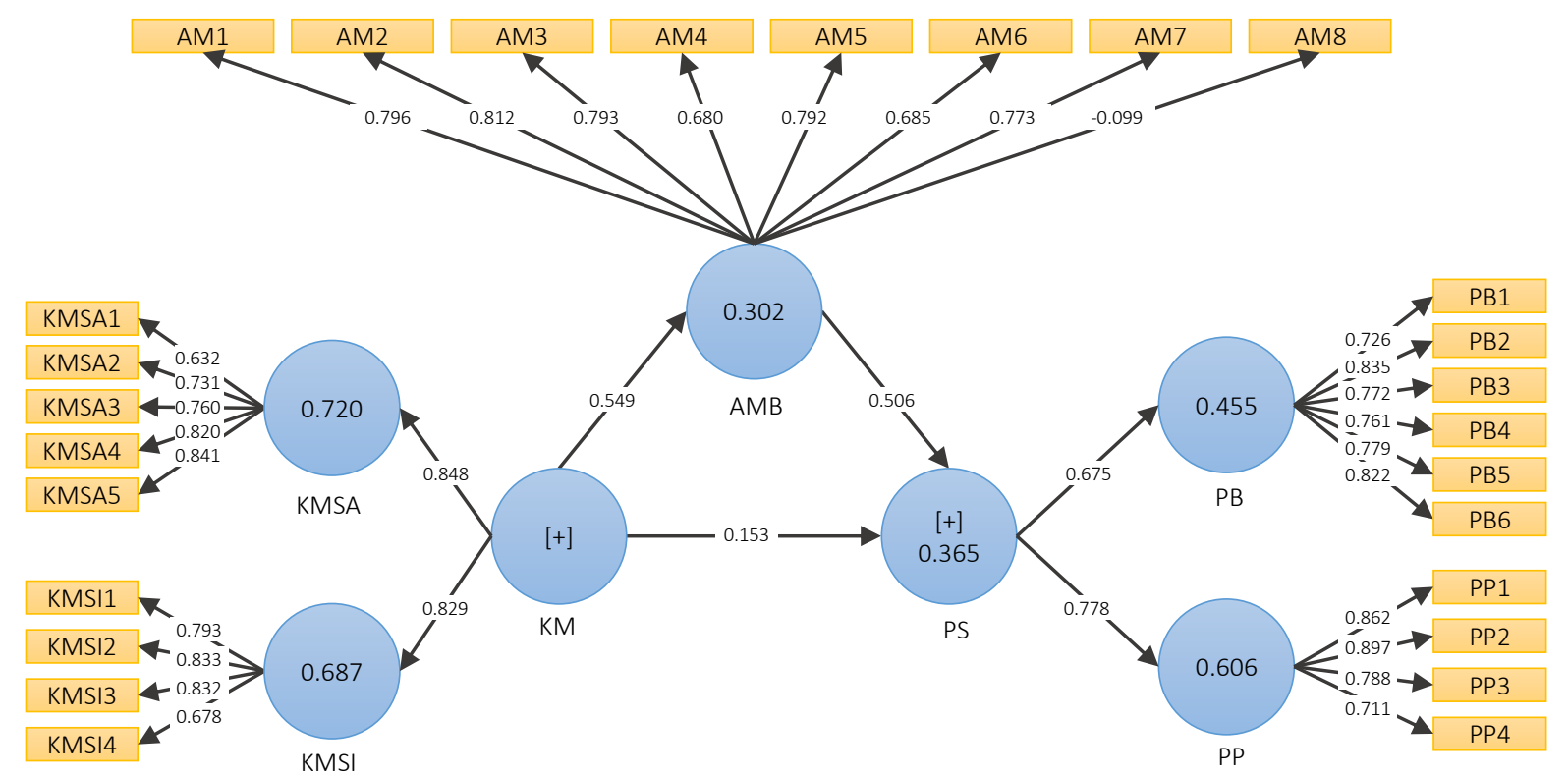

Figure 2. Research measurement model

Sarstedtl, 2016). Reflective scales have an Average Variance Extracted (AVE) values that ranged between 0.511 and 0.668 , which exceeds the minimum requirements of AVE, which should be more than 0.50 (Johari, Yahya, \& Omar, 2011, Hair, Hult, Ringle, \& Sarstedtl, 2016). Also, the discriminant validity was considered to be satisfactory, because the Heterotrait-Monotrait Ratio (HTMT) criteri- on for two combinations of constructs was lower than the threshold level of 0.90 , as suggested by Henseler, Ringle, and Sarstedt (2015), Hair, Hult, Ringle, and Sarstedtl (2016). Conclusively, the content, convergent, and discriminant validity of the research constructs have been confirmed. So, construct validity and reliability have been established in this study.

Table 1. Internal consistency and convergent validity

\begin{tabular}{|c|c|c|c|c|c|}
\hline Main construct & Indicators & Loadings & CA & CR & AVE \\
\hline \multirow{8}{*}{ Ambidexterity related factor } & AM1 & 0.796 & 0.824 & 0.875 & 0.511 \\
\hline & AM2 & 0.812 & $\ldots$ & $-\ldots$ & - \\
\hline & AM3 & 0.793 & - & - & - \\
\hline & AM4 & 0.680 & - & - & - \\
\hline & AM5 & 0.792 & $-\ldots$ & $-\ldots$ & $-\ldots$ \\
\hline & AM6 & 0.685 & - & - & - \\
\hline & AM7 & 0.773 & - & - & - \\
\hline & AM8 & 0.799 & - & $-\cdots$ & - \\
\hline \multirow{9}{*}{ Knowledge management related factor } & KMSA1 & 0.632 & 0.819 & 0.871 & 0.578 \\
\hline & KMSA2 & 0.731 & - & - & - \\
\hline & KMSA3 & 0.760 & - & - & - \\
\hline & KMSA4 & 0.820 & - & - & - \\
\hline & KMSA5 & 0.841 & - & - & - \\
\hline & KMSI1 & 0.793 & 0.791 & 0.866 & 0.618 \\
\hline & KMSI2 & 0.833 & - & - & - \\
\hline & KMSI3 & 0.832 & - & - & - \\
\hline & KMSI4 & 0.678 & - & - & - \\
\hline \multirow{10}{*}{$\begin{array}{l}\text { Project success (project benefits and performance) } \\
\text { related factor }\end{array}$} & PB1 & 0.726 & 0.874 & 0.905 & 0.614 \\
\hline & PB2 & 0.835 & - & $-\ldots$ & - \\
\hline & PB3 & 0.772 & - & - & - \\
\hline & PB4 & 0.761 & - & - & - \\
\hline & PB5 & 0.779 & - & - & - \\
\hline & PB6 & 0.822 & - & - & - \\
\hline & PP1 & 0.862 & 0.832 & 0.889 & 0.668 \\
\hline & PP2 & 0.897 & - & - & - \\
\hline & PP3 & 0.788 & - & - & - \\
\hline & PP4 & 0.711 & - & - & - \\
\hline
\end{tabular}

Note: CA: Cronbach's Alpha; CR: Composite Reliability; AVE: Average Variance Extracted. 
Table 2. Discriminant Validity Heterotrait-Monotrait Ratio (HTMT)

Source: Authors.

\begin{tabular}{l|c|c|c|c|c}
\hline \multicolumn{1}{c}{ Constructs } & AMB & KMSA & KMSI & PB & PP \\
\hline AMB & - & - & - & - & - \\
KMSA & 0.460 & 0.618 & 0.451 & - & - \\
KMSI & 0.176 & 0.137 & 0.220 & - \\
PB & 0.828 & 0.438 & 0.559 & - \\
PP & & - & - & - \\
\hline
\end{tabular}

Note: AMB: Ambidexterity; KMSA: Knowledge Management (Sharing and Application); KMSI: Knowledge Management (Storage and Integration); PP: Project Performance; PB: Project Benefits.

From Figure 2, the value for $R$-squared was 0.365, which indicated that, in the model, latent variables (exogenous), which are KM and ambidexterity, explain $37 \%$ of the variance of the endogenous latent variable (i.e., project success), which is statistically moderate and also acceptable (Cohen, 1988).

The data in Figure 3 and Table 3 show the results of the structural equation model and testing the mediation effect. The direct path concerning relationship between $\mathrm{KM}$ and project success (KM $\rightarrow \mathrm{PS}$ ), $\mathrm{KM}$ and ambidexterity (KM $\rightarrow \mathrm{AMB})$, and ambidexterity and project success (AMB $\rightarrow$ PS) are all significant and positive $(\boldsymbol{\beta}=0.171, t=2.536$, $p<0.005 ; \boldsymbol{\beta}=0.556, t=11.769, p<0.001 ; \boldsymbol{\beta}=0.615$, $t=11.692, p<0.001)$. As shown in the stated results, Hypothesis 1 that proposed that "KM has a positive effect on project success" is supported. The indirect effect $(\mathrm{KM} \rightarrow \mathrm{AMB} \rightarrow \mathrm{PS} \quad(\boldsymbol{\beta}=0.342$, $t=10.157, p<0.01)$ is also significant and positive, and the obtained 95\% Confidence Interval (CI) does not consist of zero. Therefore, it may be stated that ambidexterity partly mediates the relationship between KM and project success. Hence, Hypothesis 2 is also accepted and supported. In the present mediation model, ambidexterity denotes an appropriate mechanism for explaining the relationship between KM and project success. Hence, what necessitates the positive indirect role through the (ambidexterity) as a mediator variable exposes the 'true' relationship that exists between KM and project success (Hair, Black, Babin, \& Anderson, 2014).

Furthermore, the result from the structural model analysis established the effect size (f2) value of 0.505 and 0.281 , respectively, defined that the latent exogenous constructs have a significant influence on the latent endogenous construct. It suggests that project performance is explained by KM and ambidexterity with the effect size value (Hussain, Fangwei, Siddiqi, Ali, \& Shabbir, 2018; Hair, Black, Babin, \& Anderson, 2014; Cohen, 1988). This indicates that KM has a large effect on project success, while ambidexterity has a moderate effect on project success. Besides, the Cross Validated Redundancy (CVR) value is 0.102 . The research model has an acceptable predictive relevance, as indicated by Chin (2010), Aktar, D'Ambra, and Ray (2011).

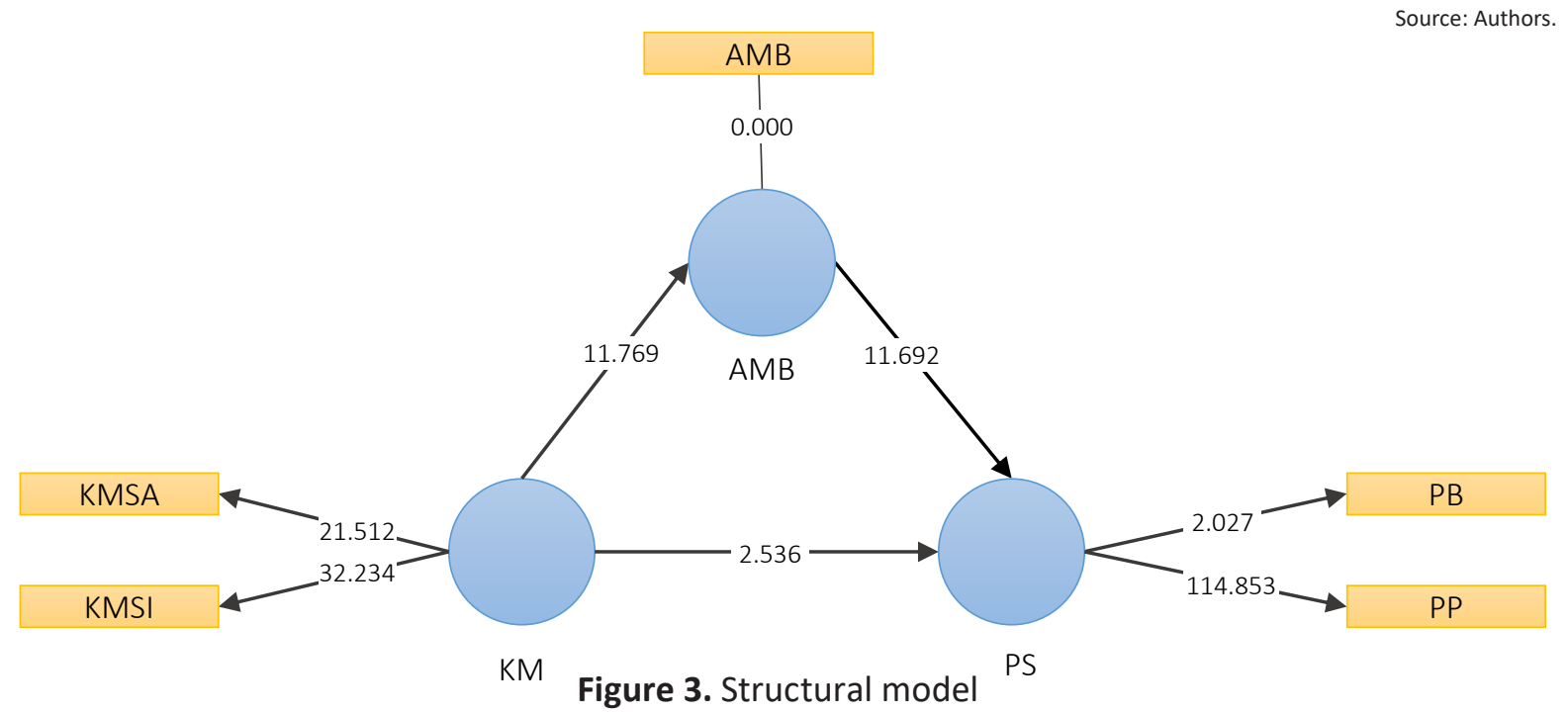


Table 3. Hypotheses testing

\begin{tabular}{|c|c|c|c|c|c|c|c|}
\hline Paths & Beta & St. dev. & $t$-stat & $p$-values & $2.5 \%$ & $97.5 \%$ & Decision \\
\hline \multicolumn{8}{|c|}{ Direct paths } \\
\hline $\mathrm{AMB} \rightarrow \mathrm{PS}$ & 0.615 & 0.053 & 11.692 & 0.000 & 0.506 & 0.707 & Supported \\
\hline $\mathrm{KM} \rightarrow \mathrm{AMB}$ & 0.556 & 0.047 & 11.769 & 0.000 & 0.461 & 0.646 & Supported \\
\hline $\mathrm{KM} \rightarrow \mathrm{PS}$ & 0.171 & 0.068 & 2.536 & 0.012 & 0.052 & 0.318 & Supported \\
\hline \multicolumn{8}{|c|}{ Mediating effect } \\
\hline $\mathrm{KM} \rightarrow \mathrm{AMB} \rightarrow \mathrm{PS}$ & 0.342 & 0.034 & 10.157 & 0.000 & 0.273 & 0.412 & Supported \\
\hline
\end{tabular}

The results of the research show that KM is an integral aspect of project success. It has a significant positive effect on project success, highlighting that KM is a significant factor that influences project success in terms of project performance and benefits concerning meeting cost, schedule, safety and quality, and benefits to customers and businesses. Furthermore, the results showed that ambidexterity mediates the relationship between knowledge management and project success. Subsequently, the entire hypothesis in this research was supported.

\section{DISCUSSION}

The findings of this research are consistent with some of the extant literature. According to Cleland (1994), KM is crucial to the accomplishment of project success. Successful projects are the building blocks to implement the changes in an organization, which, in the long term, facilitates the accomplishment of organizational strategic objectives (Nasiruzzaman, Qudaih, \& Dahlan, 2013). The findings of this study also suggest that KM can help transfer new knowledge into innovation. Likewise, it furthermore helps improve project success and performance by gaining greater understanding and use of innovation knowledge.

KM can produce intangible resources in a more innovative method and is a vital driver for a successful project outcome, given the vital position of communication and knowledge sharing in business operations (Yang, Chen, \& Wang, 2012). Kotlarsky and Oshri (2005) found that knowledge sharing and communication have a positive relationship with successful collaboration in project teams by two indicators, product success, and personal satisfaction, confirming that knowledge integration and sharing are more likely to result in making the project more effective. Further, the findings of this research show that the benefits of the project can be achieved by enhancing knowledge sharing and application and knowledge storage and inclusion.

Leveraging the findings of this study, it can be asserted that $\mathrm{KM}$, involving knowledge sharing and application and knowledge storage and integration, is a catalyst for an effective and successful project. Change is constant in the current dynamic environment, and program managers should embrace and exploit the changes. Thus, it is essential to ensure integrating knowledge bases to accomplish projects. Knowledge integration is subject to the people's capability to establish a relationship with each other, endure sharing and realize findings and knowledge assets created in the project environment, and adapt them to the swiftness of other sections of the project. Further, in the project where KM is well-entrenched, people would effectively incorporate their own held knowledge assets, which will guarantee project success.

Furthermore, the results of this study also highlight the importance of organizational ambidexterity. Based on the results, it could be inferred that KM, which does not induce ambidexterity, could not significantly enhance project success. $\mathrm{KM}$ can induce and stimulate enhanced project performance and benefits only when it induces ambidexterity. This is because ambidexterity helps an organization to test its market and external environment simultaneously, further leverage its own knowledge base and assets to enhance higher performance and achieve sustainable competitive advantages (Kim, Lim, \& Yoo, 2019; Petro, 2017). As mentioned previously, ambidexterity helps to achieve the simultaneous capacity to manage current business challenges efficiently while con- 
currently having the capacity to cope with future business changes. Ambidextrous organizations are well-positioned to handle the environmental challenges, and they are very efficient in meet- ing most of today's demands and quite adaptive in handling the ever-changing market conditions (Jurksiene \& Pundziene, 2016; Teece, Peteraf, \& Leih, 2016).

\section{CONCLUSION}

As organizations are becoming more project-oriented, and management-by-projects are becoming part of the organizational strategies, organizations want effective good, and service delivery cum enhanced positive outcomes and benefits. However, this would require that project management be integrated with KM, which will induce ambidexterity and project success in the long run. This study has implications for the stakeholders in that the advanced technology and environmental changes precipitate the existing challenges and thus accurate information must be easily located, trusted by people and used to solve a particular problem, to respond to a threat or issue, to satisfy the fear of a stakeholder, and to enhance the process of product development or provision of the service needed. For proper learning, there should be an effective knowledge sharing and knowledge transfer. Also, organizations need to solve a particular problem, respond to a risk or challenge, satisfy the fear of a stakeholder, and advance product development or the delivery of the necessary service.

Overall, this study has provided more insights and advances the body of knowledge further in project management research. However, the findings of the study should be cautiously generalized, given that it covers only the manufacturing sector in Jordan. The model of the research can be replicated in other contexts to solidify the findings of the current study.

\section{REFERENCES}

1. Ajmal, M. M., Sandhu, M. A., \& Jabeen, F. (2013). Assessment of knowledge management practices in project-oriented business. International Journal of Project Organization and Management, 5(3), 279-292. https://doi. org/10.1504/IJPOM.2013.055856

2. Aktar, S., D’Ambra, J., \& Ray, P. (2011). An evaluation of PLS based complex models: the roles of power analysis, predictive relevance and GoF index. In Proceedings of the $17^{\text {th }}$ American Conference on Information Systems (AMCIS2011) (pp. 1-7). Detroit, USA: Association for Information Systems.

3. Al-Hawary, S. I. S., \& Alwan, A. M. (2016). Knowledge Management and Its Effect on Strategic Decisions of Jordanian Public Universities. Journal of Accounting, Business \& Management, 23(2), 21-41. Retrieved from http://journal.stiemce.ac.id/index.php/jabminternational/article/view/106

4. Al-Zayyat, A. N., Al-Khaldi, F., Tadros, I., \& Al-Edwan, G.
(2010). The effect of knowledge management processes on project management. Journal of IBIMA Business Review, 1-6. https://doi org/10.5171/2010.826105

5. Anderson, J., \& Gerbing, D. (1988). Structural equation modelling in practice: a review and recommended two-step approach. Psychological Bulletin, 103(3), 411423. https://doi.org/10.1037/00332909.103.3.411

6. Arthur, M. B., DeFillippi, R. J., \& Jones, C. (2001). Project-based learning as the interplay of career and company non-financial capital. Management Learning, 32(1), 99-117. https://doi. org/10.1177/1350507601321007

7. Candi, M., Van den Ende, J., \& Gemser, G. (2013). Organizing innovation projects under technological turbulence. Technovation, 33(4), 133-141. https://doi.org/10.1016/j.technovation.2013.01.002

8. Chen, C. J., \& Huang, J. W. (2009). Strategic human resource practices and innovation performance the mediating role of knowledge management capacity. Journal of Business Research, 62(1), 104114. https://doi.org/10.1016/j. jbusres.2007.11.016

9. Cohen, J. (1988). Statistical power analysis for the behavioral sciences (2nd ed.). Hillsdale, NJ: Lawrence Erlbaum.

10. Fedor, D. B., Ghosh, S., Caldwell, S. D., Maurer, T. J., \& Singhal, V. R. (2003). The effects of knowledge management on team members' ratings of project success and impact. Decision Sciences, 34(3), 513-539. https://doi.org/10.1111/ j.1540-5414.2003.02395.x

11. Fornell, C., \& Yi, Y. (1992). Assumptions of the two-step approach: reply to Anderson and Gebing. Sociological Methods and Research, 20(3), 334-339. https://doi.org/10.1177/0049124192020003003

12. Gelbard, R., \& Carmeli, A. (2009). The interactive effect of 
team dynamics and organizational support on ICT project success. International Journal of Project Management, 27(5), 464-470. https://doi.org/10.1016/j.ijproman.2008.07.005

13. Gibson, C., \& Birkinshaw, J. (2004). The antecedents, consequences, and mediating role of organizational ambidexterity. Academy of Management Journal, 47(2), 209-226. https://doi. org/10.5465/20159573

14. GlobalEDGE. (2018). Jordan: Economy 2018. Retrieved from https://globaledge.msu.edu/countries/jordan/economy (accessed on February 21, 2018).

15. Güttel, W., \& Konlechner, S. (2007). Dynamic capabilities and competence obsolescence: empirical data from research-intensive firms. In Proceedings of OLKC - "Learning Fusion" (pp. 357-374). Retrieved from https://www.researchgate.net/ publication/228916849_Dynamic_ capabilities_and_competence_obsolescence_empirical_data_from_research-intensive_firms

16. Hair, J. F., Black, W. C., Babin, B. J., \& Anderson, R. E. (2010). Multivariate data analysis: A Global Perspective (7th ed.). Upper Saddle River, NJ: Pearson.

17. Hair, J. F., Black, W. C., Babin, B. J., \& Anderson, R. E. (2014). Multivariate data analysis: Pearson new international edition (7th ed.). Pearson Prentice Hall.

18. Hair, J. F., Hult, G. T. M., Ringle, C., \& Sarstedt, M. (2016). A primer on partial least squares structural equation modeling (PLS-SEM). Sage Publications, Inc.

19. Hanisch, B., Lindner, F., Mueller, A., \& Wald, A. (2009). Knowledge management in project environments. Journal of Knowledge Management, 13(4), 148-160. Retrieved from https://www.deepdyve.com/lp/emerald-publishing/ knowledge-management-in-projectenvironments-s5NfRQGzJL

20. He, Z., \& Wong, P. (2004). Exploration vs. Exploitation: An Empirical Test of the Ambidexterity Hypothesis. Organization Science, 15(4), 481-496. https://doi. org/10.1287/orsc. 1040.0078
21. Henseler, J., Ringle, C., \& Sarstedt, M. (2015). A new criterion for assessing discriminant validity in variance-based structural equation modeling. Journal of the Academy of Marketing Science, 43(1), 115-135. https://doi.org/10.1007/s11747-0140403-8

22. Huang, J. W., \& Li, Y. H. (2009). The mediating effect of knowledge management on social interaction and innovation performance. International Journal of Manpower, 30(3), 285-301. https://doi. org/10.1108/01437720910956772

23. Hussain, S., Fangwei, Z., Siddiqi, A., Ali, Z., \& Shabbir, M. (2018). Structural equation model for evaluation factors affecting quality for social infrastructure projects. Sustainability, 10(5), 1415, 1-25. https://doi.org/10.3390/su10051415

24. Johari, J., Yahya, K., \& Omar, A. (2011). The construct validity of organizational structure scale: evidence from Malaysia. World Journal of Management, 3(2), 131-152. Retrieved from https:// www.academia.edu/27527287/ The_construct_validity_of_organizational_structure_scale_Evidence_ from_Malaysia

25. Jurksiene, L., \& Pundziene, A. (2016). The relationship between dynamic capabilities and firm competitive advantage: The mediating role of organizational ambidexterity. European Business Review, 28(4), 431-448. https://doi. org/10.1108/EBR-09-2015-0088

26. Katila, R., \& Ahuja, G. (2002). Something old, something new: A longitudinal study of search behavior and new product introduction. Academy of Management Journal, 45(6), 1183-1194. https://doi. org/10.5465/3069433

27. Keeter, S. (2005). Survey Research. In D. Druckman (Ed.), Doing research: Methods of Inquiry for conflict analysis (pp. 123162). Thousand Oaks, CA: Sage Publications, Inc.

28. Kerzner, H. (2011). Project Management Metrics, KPIs and Dashboards. New Jersey: John Wiley and Sons.
29. Kim, C. Y., Lim, M. S., \& Yoo, J. W. (2019). Ambidexterity in external knowledge search strategies and innovation performance: mediating role of balanced innovation and moderating role of absorptive capacity. Sustainability, 11(5111), 1-23. https://doi.org/10.3390/ su11185111

30. Kotlarsky, J., \& Oshri, I. (2005). Social ties, knowledge sharing and successful collaboration in globally distributed system development projects. European Journal of Informational Systems, 14(1), 37-48. https://doi.org/10.1057/palgrave. ejis.3000520

31. Lenfle, S., \& Loch, C. (2010). Lost roots: How project management came to emphasize control over flexibility and novelty. California Management Review, 53(1), 32-55. Retrieved from http://www.sylvainlenfle.com/images/Publications/ Lost_Roots_R2_VF.pdf

32. Lis, A., Józefowics, B., Tomanek, M., \& Gulak-Lipka, P. (2018). The concept of the ambidextrous organizations: systematic literature review. International Journal of Contemporary Management, 17(1), 77-79. http://dx.doi.org/10.4467/244 98939IJCM.18.005.8384

33. Liu, P. L., Chen, W. C., \& Tsai, C. H. (2005). An empirical study on the correlation between the knowledge management method and new product development strategy on product performance in Taiwan's industries. Technovation, 25(6), 637-644. https://doi.org/10.1016/j. technovation.2003.11.001

34. March, J. (1991). Exploration and exploitation in organizational learning. Organization Science, 2(1), 71-86. https://doi.org/10.1287/ orsc.2.1.71

35. Nasiruzzaman, Md., Qudaih, $\mathrm{H}$. A., \& Dahlan, A. R. A. (2013). Project Success and Knowledge Management (KM) Practices in Malaysian Institution of Higher Learning (IHL). Journal of Education and Vocational Research, 4(5), 159-164. Retrieved from https://www.researchgate.net/publication/329356810_Project_Success_ and_Knowledge_Management_ KM_Practices_in_Malaysian_Institution_of_Higher_Learning_IHL 
36. O'Reily, C., \& Tushman, M. (2011). Organizational ambidexterity in action: how managers explore and exploit. California Management Review, 35(4), 1-18. https://doi. org/10.1525\%2Fcmr.2011.53.4.5

37. Petro, Y. (2017). Ambidexterity through Project Portfolio Management Resolving paradoxes in organizations (Doctoral dissertation). The British University in Dubai (BUiD). Retrieved from https://bspace.buid.ac.ae/handle/1234/1096

38. Pinto, J. K., \& Slevin, D. P. (1988). Project success: definitions and measurement techniques. Project Management Journal, 19(1), 67-72. Retrieved from https://www.pmi. org/learning/library/projectsuccess-definitions-measurementtechniques-5460

39. Prabhakar, P. G. (2008). What is project success: a literature review. International Journal of Business and Management, 3(9), 3-10. https://doi. org/10.5539/ijbm.v3n9p3

40. Raisch, S., \& Birkinshaw, J. (2008). Organizational ambidexterity: antecedents, outcomes, and moderators. Journal of Management, 34(3), 375-409. https://doi. org/10.1177/0149206308316058

41. Raisch, S., Birkinshaw, J., Probst, G., \& Tushman, M. (2009). Organizational ambidexterity: balancing exploitation and exploration for sustained performance. Organization Science, 20(4), 685-695. https://doi. org/10.1287/orsc.1090.0428

42. Revilla, E., Prieto, I., \& Rodríguez, B. (2011). Information technology and the ambidexterity hypothesis: an analysis in product development. Journal of Operations and Supply Chain Management, 4(2), 1-18. https://doi.org/10.22004/ ag.econ. 289365

43. Robinson, H., Carrillo, P., Anumba, C., \& Al-Ghassani, A. (2005). Knowledge management practices in large construction organizations. Engineering Construction and Architectural Management, 12(5), 431-445. https://doi. org/10.1108/09699980510627135
44. Sage, D. J., Dainty, A. R., \& Brookes, N. J. (2010). Who reads the project file? Exploring the power effects of knowledge tools in construction project management. Construction Management and Economics, 28(6), 629-639. https://doi. org/10.1080/01446191003725154

45. Santo, S. A. (2005).

Knowledge management: An imperative for schools of education. TechTrends, 49(6), 42-49. https://doi.org/10.1007/BF02763729

46. Sekaran, U. (2003). Research methods for business: A skill building approach (4th ed.). New York: John Wiley \& Sons, Inc.

47. Sekaran, U., \& Bougie, R. (2010) Research methods for business: $A$ skill-building approach (5th ed.). Chichester: John Wiley \& Sons.

48. Styhre, A., \& Gluch, P. (2010). Managing knowledge in platforms: boundary objects and stocks and flows of knowledge. Construction Management and Economics, 28(6), 589-599. https://doi. org/10.1080/01446190903450061

49. Szulanski, G. (1996). Exploring internal stickiness: Impediments to the transfer of best practice within the firm. Strategic Management Journal, 17(2), 27-43. https://doi. org/10.1002/smj.4250171105

50. Tamayo-Torres, J., Roehrich, J., \& Lewis, M. (2017). Organizational ambidexterity, manufacturing performance and environmental dynamism. International Journal of Operations \& Production Management, 37(3), 282-299. Retrieved from https://papers.ssrn. com/sol3/papers.cfm?abstract $\mathrm{id}=2955122$

51. Teece, D., Peteraf, M., \& Leih, S. (2016). Dynamic capabilities and organizational agility. California Management Review, 58(4), 13-35. https://doi.org/10.1525/ cmr.2016.58.4.13

52. Todorović, M. L., Petrović, D. Č., Mihić, M. M., Obradović, V. L., \& Bushuyev, S. D. (2015). Project success analysis framework: A knowledge-based approach in project management. International Journal of Project Management, 33(4), 772-783. Retrieved from https://daneshyari.com/article/preview/276346.pdf

53. Turner, J. (2009). The Handbook of Project-Based Management. London: Mc-Graw Hill.

54. Turner, J. R., Keegan, A., \& Crawford, L. (2004). Learning by experience in the project-based organization. Proceedings of the PMI Research Conference 2004. Project Management Institute, PA: Newtown Square. Retrieved from https://www.pmi.org/learning/ library/learning-experience-projectbased-organization-8534

55. Tushman, M., \& O’Reilly, C. (1996). Ambidextrous organizations: managing evolutionary and revolutionary change. California Management Review, 38(4), 8-30. Retrieved from http://web. mit.edu/curhan/www/docs/ Articles/15341_Readings/Organizational_Learning_and_Change/ Tushman_\&_OReilly_1996_Ambidextrous_Organizations.pdf

56. Wilson, J. (2010). Essentials of business research - A guide to doing your research project. New Delhi: SAGE Publications India.

57. Yahya, S., \& Goh, W. K. (2002). Managing human resources toward achieving knowledge management. Journal of Knowledge Management, 6(5), 457-468. https://doi. org/10.1108/13673270210450414

58. Yang, L. R., Chen, J. H., \& Wang, H. W. (2012). Assessing impacts of information technology on project success through knowledge management practice. Automation in Construction, 22, 182-191. https://doi.org/10.1016/j.autcon.2011.06.016

59. Yun, G., Shin, D., Kim, H., \& Lee, S. (2011). Knowledgemapping model for construction project organizations. Journal of Knowledge Management, 15(3), 528-548. https://doi. org/10.1108/13673271111137475

60. Zhang, Y., Wei, F., \& Constance, V. (2019). Individual ambidexterity and antecedents in a changing context. International Journal of Innovation Management, 23(3), 1-25. https://doi.org/10.1142/ S136391961950021X 